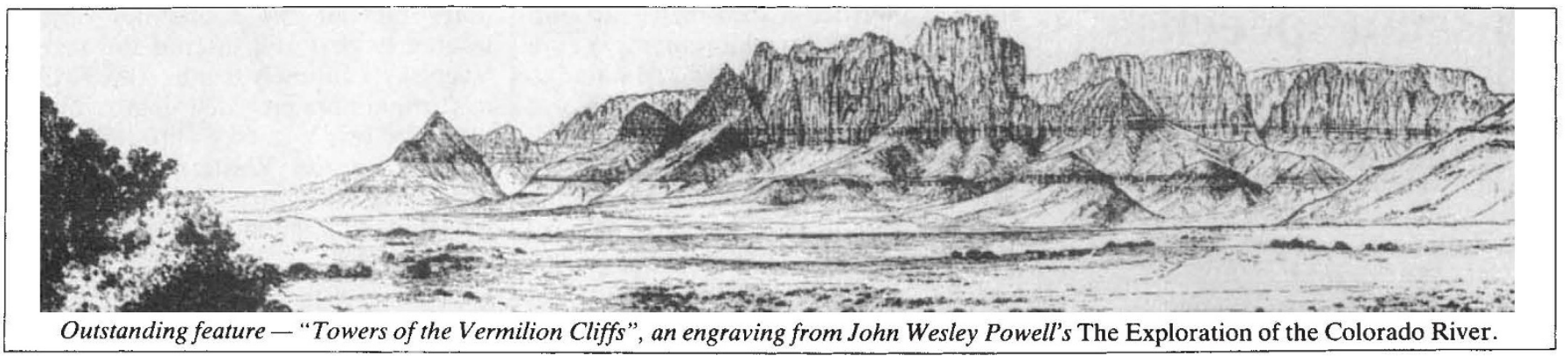

This little-known work by the famed author of Walden, he points out, is "unusual even by Thoreau's standards, because it is good-natured about the bleakest of subjects, it is only glancingly about the Cape (its real subject is the sea), and contains more reverie than actual experience". Essentially it is a book about beachcombing - but beachcombing elevated almost into a spiritual commitment. Like W.H. Hudson, that self-styled "traveller in little things" with whom he has sometimes been compared, Thoreau specialized in the sort of minor observations and incidents which most other authors consider beneath their regard, allowing his narrative to wander about here and there, as seemingly aimless as his feet. Between them the two constitute nature writing's picaresque wing.

Though stereotyped as a loner, Thoreau gives evidence enough in this book of at least being interested in the people that he happened to encounter. What is more, on two out of the three short excursions (made in 1849-1855) on which it is based he had a friend as his companion. Even worse for the image, the book was a product of what would appear to have been a calculated bit of worldliness: it originally consisted of ten separate articles, written at a time when he was supporting himself by lecturing and journalism. Eleven years after Walden and three years after his comparatively early death, the unity of the pieces was recognized and they were successfully disinterred. Quite apart from their literary attractions, they possess a certain interest for the historian as well. For they were written at just about the time that Philip Henry Gosse was attracting an unexpectedly large following with his entrancingly illustrated guides to the life of the seashore on the other side of the Atlantic. It seems more than possible that Thoreau's publisher, aware of this, decided to lure him away from his hitherto land-locked existence and try to produce in him an American answer to Gosse. "Having come so fresh to the sea", Thoreau is frank enough to admit, "I have got but little salted". Did he realize, one wonders, that he risked disappointing posterity by showing himself as opportunistic?

Unlike the other three books, Prishvin's Nature's Diary is a work of the twentieth century. Unlike them, too, it is a trans- lation and it comes from a different continent. As its introducer, John Updike suffers from the disadvantage of not knowing the area described and is reduced to reminding us of the scenery at second hand, through the eyes of such as Tolstoy and Turgenev. Much-travelled, widely read, a one-time student in Leipzig, Prishvin had an extra coating of sophistication to shed before he was able to approach nature with the necessary directness of response. His book is not a continuous narrative, but consists of unrelated journal extracts which inevit-

\section{Doom again}

\section{Kenneth Mellanby}

Earth. By Anne H. Ehrlich and Paul R. Ehrlich. Thames Methuen, London/ Franklin Watts, New York: 1987. Pp.258. $£ 14.95, \$ 19.95$.

AN UNKIND reporter of a scientific conference is often tempted to say "Professor Blank gave his lecture". Similarly I am tempted to say "Professor Ehrlich has published his book". Over the past 20 years, Paul Ehrlich, sometimes alone, sometimes in collaboration with his wife, Anne Ehrlich, or with one of his other colleagues, has written a series of books all of which contain essentially the same information. Only a year ago he produced The Machinery of Nature. In 1966 his first major contribution was The Population Bomb. In between we have had Popula tion, Resources, Environment in 1970, Ecoscience in 1977 and a great many articles in many different magazines.

It would be wrong to say that these books are all only slight modifications of the same text. Like a skilled chef, Ehrlich has used the same ingredients to produce a considerable variety of dishes. For one thing, the books vary considerably in size and in the detail in which the information is presented. They are intended to appeal to different audiences, from professional scientists to the general public. Earth is perhaps the most popular of all, and is aimed at the audience expected to watch a television series shown in Britain earlier this year. Like all his books, it is well written. It is rather more lavishly illustrated ably give it a rather disjointed character. Its affinity is rather with belles lettres and with the selfconscious nature essayists than with the higher travel-writing of Muir and Powell. Devotees of Thoreau may nevertheless find it an interesting comparison - though they are unlikely to approve of the author's egg-collecting and his frequent resort to the gun.

David E. Allen, Lesney Cottage, Middle Road, Winchester, Hampshire SO22 5EJ, UK, is a past President of the Society for the History of Natural History. His most recent book is The Botanists (St Paul's Bibliographies, 1986).

than most of the earlier works. Had they not been published, this new one would for the most part have been warmly welcomed.

The information presented in so many ways in Ehrlich's books consists first of an introduction to global ecology, well and clearly expressed. We are then given a picture of the world today, with particular stress on the terrible things that mankind is doing to the environment. Finally we have a forecast of the future. My main criticism is that when describing the world today, the most gloomy picture is always given, and any report of damage, however tentative, is stated as fact.

There has, however, been some change over the years. In 1969, in an article entitled "Eco-catastrophe", Ehrlich forecast the death of the oceans, and "almost instant starvation" in Japan and China well before 1980 . He makes no references to this and other dreadful but unfulfilled prophesies in his more recent works. Although still a prophet of doom, the picture is a little less pessimistic than that presented 20 years ago. Overpopulation by man is still seen to be the greatest danger, but the possibility of population control within the world's carrying capacity is no longer considered impossible.

Professor Ehrlich is a highly respected ecologist, and he has made many valuable contributions to science. It is unfortunate that he is unable to exercise the rigour he clearly uses in the laboratory when he becomes involved in world affairs.

Kenneth Mellanby, 38 Warkworth Street, Cambridge CBI IEG, UK, was formerly Director of Monks Wood Experimental Station, Huntingdon. Among other books he is author of Farming and Wildlife (Collins, 1981). 